ks. Wiesław Przyczyna ${ }^{1}$

Uniwersytet Papieski Jana Pawła II w Krakowie

\title{
Nauczanie papieża Franciszka o uchodźcach podczas Światowych Dni Młodzieży w Krakowie w relacjach dziennikarzy katolickich portali internetowych
}

W dniach od 26 do 31 lipca 2016 roku odbywały się w Krakowie Światowe Dni Młodzieży. Uczestniczył w nich papież Franciszek, który w swoich przemówieniach poruszył ważne i aktualne tematy religijne i społeczne.Jednym z nich był temat uchodźców ${ }^{2}$, szeroko komentowany w mediach. W tym kontekście zasadne jest pytanie: Jak nauczanie to było relacjonowane na stronach katolickich portali internetowych? Poszukując na nie odpowiedzi, przytoczymy najpierw fragmenty papieskich przemówień poruszające temat uchodźców, nie opatrując ich komentarzem. Następnie zestawiamy

1 Ks. Wiesław Przyczyna, prof. dr hab., homileta i teolingwista, dyrektor Instytutu Liturgicznego i kierownik Katedry Komunikacji Religijnej Uniwersytetu Papieskiego Jana Pawła II w Krakowie, członek Prezydium Rady Języka Polskiego przy Prezydium Polskiej Akademii Nauk, członek Komitetu Nauk Teologicznych PAN, przewodniczący Komisji Języka Religijnego przy Międzynarodowym Komitecie Slawistów, mieszka w Krakowie, e-mail: wieslaw.przyczyna@upjp2.edu.pl. uchodźcom. 
je z cytatami pochodzącymi z tekstów, które zostały zamieszczone na stronach katolickich portali internetowych. Kryterium doboru tych cytatów będzie odniesienie do słów papieża Franciszka związanych z uchodźcami³

\section{Papieskie nauczanie o uchodźcach}

Przemówienia papieża podczas Światowych Dni Młodzieży w Krakowie miały zasadniczo charakter oficjalny. Oprócz wystąpień w tzw. oknie papieskim, kiedy papież starał się wchodzić w spontaniczny dialog z oczekującą na niego młodzieżą, przemawiał zazwyczaj w związku z oficjalnymi uroczystościami. Główne przemówienia łączyły się z mszami (homilie), nabożeństwami czy oficjalnymi wizytami. Temat uchodźców pojawił się w sześciu przemówieniach: 27 lipca na Wawelu podczas oficjalnego powitania i w katedrze wawelskiej na spotkaniu z biskupami, 28 lipca na krakowskich Błoniach z okazji pierwszego spotkania z młodzieżą i 29 lipca również na krakowskich Błoniach w czasie drogi krzyżowej, 30 lipca w Łagiewnikach, 30 lipca w Brzegach koło Krakowa ${ }^{4}$. Mówił wtedy:

Ta ostatnia kwestia [uchodźców] wymaga dodatkowo mądrości i miłosierdzia, aby przezwyciężyć lęki i zrealizować największe dobro. Trzeba zidentyfikować przyczyny emigracji z Polski, ułatwiając powrót osobom, które chcą wrócić. Jednocześnie potrzebna jest gotowość przyjęcia ludzi uciekających od wojen i głodu; solidarność z osobami pozbawionymi swoich praw podstawowych, w tym do swobodnego i bezpiecznego wyznawania swojej wiary. Równocześnie należy zabiegać o współpracę i koordynację na poziomie międzynarodowym, w celu znalezienia rozwiązania konfliktów i wojen, które zmuszają wielu ludzi do opuszczenia swoich domów i ojczyzny. Chodzi zatem o uczynienie tego, co w naszej mocy, aby ulżyć ich cierpieniom, niestrudzenie, inteligentnie i stale działać na rzecz sprawiedliwości i pokoju, świadcząc konkretnymi faktami o wartościach humanistycznych i chrześcijańskich. Zachęcam naród polski, aby w świetle swojej tysiącletniej

3 Pierwsza fala uchodźców napłynęła do Europy w 2015 roku. Wśród nich 49 proc. stanowili Syryjczycy, w których kraju toczy się wojna domowa. Następni (21 proc.) byli mieszkańcy Afganistanu, gdzie od lat trwa pełzająca wojna z talibami. Irakijczyków, których część kraju zdobyło tzw. Państwo Islamskie, było 8 proc. Por. P. Wójcik, Strachy na Lachy, „Tygodnik Powszechny" 25 (2017), s. 26.

4 Wszystkie cytaty pochodzą z publikacji Laboratorium Więzi: Franciszek w Polsce. Co powiedział papież podczas Światowych Dni Młodzieży, www.laboratorium.wiez.pl (14.09.2016). 
historii patrzył z nadzieją w przyszłość i na problemy, którym musi stawić czoło (Kraków, Wawel, 27.07.2016).

W odniesieniu do imigrantów powiem, że problem tkwi tam, w ich ojczyźnie. Ale jak ich przyjmiemy? Sądzę, że każdy kraj musi zobaczyć, w jaki sposób i kiedy. Nie wszystkie kraje są równe. Nie wszystkie kraje mają takie same możliwości. [...] Ilu i jak? Nie można dać odpowiedzi uniwersalnej, ponieważ gościnność zależy od sytuacji każdego kraju, a także kultury. Ale oczywiście można zrobić wielkie rzeczy. Na przykład modlitwa: cotygodniowe adoracje Najświętszego Sakramentu (Kraków, katedra, 27.07.2016).

[...] miłosierdzie ma zawsze młode oblicze. Serce miłosierne ma bowiem odwage, by porzucić wygodę; serce miłosierne potrafi wychodzić na spotkanie innych, potrafi objąć wszystkich. Serce miłosierne potrafi być schronieniem dla tych, którzy nigdy nie mieli domu albo go stracili, potrafi stworzyć atmosferę domu i rodziny dla tych, którzy musieli emigrować, jest zdolne do czułości i współczucia. Serce miłosierne potrafi dzielić swój chleb z głodnym, serce miłosierne otwiera się, aby przyjmować uchodźców oraz imigrantów. [...] Naucz nas jak Marię z Betanii słuchania tych, których nie rozumiemy, tych, którzy pochodzą z innych kultur, innych narodów, a także tych, których się boimy, sądząc, że mogą nam wyrządzić zło (Kraków, Błonia, 28.07.2016 r.).

Darmo otrzymaliśmy, darmo dawajmy. Jesteśmy powołani, aby służyć Jezusowi ukrzyżowanemu w każdej osobie zepchniętej na margines, by dotknąć Jego błogosławionego ciała w człowieku wykluczonym, głodnym, spragnionym, nagim, uwięzionym, chorym, bezrobotnym, prześladowanym, uchodźcy, imigrancie. Tam znajdziemy naszego Boga, tam możemy dotykać Pana (Kraków, Błonia, 29.07.2016).

[...] niech nasza Matka Miłosierdzia uczy nas troszczyć się konkretnie o rany Jezusa w naszych potrzebujących braciach i siostrach, zarówno bliskich, jak i dalekich, chorego i migranta (Kraków, Łagiewniki, 30.07.2016).

Pójść na ulice, naśladując „szaleństwo” naszego Boga, który uczy nas spotykania Go w głodnym, spragnionym, nagim, chorym, w przyjacielu, który źle skończył, w więźniu, w uchodźcy i w imigrancie, w człowieku bliskim, który jest samotny (Brzegi, 30.07.2016 r.).

\section{Nauczanie papieskie o uchodźcach w ujęciu dziennikarzy portali katolickich}

Teksty komentujące nauczanie papieskie o uchodźcach pochodzą ze stron internetowych informacyjnych portali katolickich z okresu od 25 lipca do 2 sierpnia 2016 roku, czyli bezpośrednio związanego z przebiegiem Światowych Dni Młodzieży. Wybrane zostały trzy największe opiniotwórcze 
portale: deon.pl, fronda.pl i wiara.pl. Wybór tych właśnie portali podyktowany był kilkoma względami. Należą one do największych w swojej kategorii, mają duże społeczne oddziaływanie, choć nie są bezpośrednio powiązane z odpowiednikami prasowymi (w odróżnieniu na przykład od portalu „Tygodnika Powszechnego”, „Gościa Niedzielnego” czy „Naszego Dziennika”) ${ }^{5}$. Są rozpoznawalne przez świeckich internautów, zwłaszcza katolików, w przeciwieństwie do innych witryn katolickich (poczytnych i opiniotwórczych), ale znanych wąskiemu gronu duchownych lub ewentualnie świeckich intensywnie zaangażowanych w życie Kościoła. I - co najważniejsze - charakteryzują się aktualnością informacji, widoczną na stronach głównych. Tutaj też można je porównać z innymi portalami, które wprawdzie są rozpoznawalne w kręgach internautów katolików, ale wiadomości widoczne na ich stronach nie są aktualizowane na bieżąco. W założeniu bowiem informacje te nie mają charakteru newsowego - skupiają się na przykład na komentarzach czy opiniach dotyczących wybranych wydarzeń. Deon.pl, wiara.pl i fronda.pl to portale, gdzie czas reakcji dziennikarskiej na bieżące wydarzenia jest niemal natychmiastowy, a wiadomości są opisem codziennych wydarzeń. Tę aktualność można było zauważyć zwłaszcza w czasie trwających Światowych Dni Młodzieży, kiedy każdy etap pielgrzymki papieskiej, związane z tym wydarzenia, a przede wszystkim przemówienia Franciszka podawane były do wiadomości publicznej i opisywane na bieżąco nawet kilka razy dziennie.

W podanym okresie na stronach tych portali ukazało się wiele tekstów tematycznie związanych z pielgrzymką papieża Franciszka do Polski. Do analizy wybrano wszystkie teksty o uchodźcach ukazujące się na stronie głównej portalu, co gwarantowało również potencjalnie największy ich zasięg. Przy okazji założono, że portale te z oczywistych powodów będą wspierać przekaz papieża Franciszka i jego nauczanie ${ }^{6}$.

[...] papież nie powiedział wcale, byśmy otworzyli się na uchodźców natychmiast i bezwarunkowo. Mówił o gotowości przyjęcia (Fronda.pl).

5 Por. D. Guzek, Konwergencja mediów katolickich w Polsce, w: Konwergencja mediów masowych i jej skutki dla wspótczesnego dziennikarstwa, t. 2, red. M. Gierula, P. Szostok, Katowice 2012, s. $227-240$.

6 Cytaty pochodzą ze stron głównych następujących portali: Deon.pl, Wiara.pl, Fronda. pl; data dostępu 25.07-02.08.2016. 
[...] w obecnych dniach, tuż po krwawych masakrach we Francji i w Niemczech w tym zabójstwie katolickiego księdza! - właśnie przez imigrantów i „uchodźców", poruszyć ten temat, nawołując do ich przyjmowania, byłoby po prostu... bardzo niezręcznie! (Fronda.pl).

Nie zabrakło także odniesienia do problemu uchodźców. Papież prosił o mądrość i miłosierdzie w podejściu do problemów migracyjnych (Fronda.pl).

Gościnność i otwarcie powinny zaś dotyczyć nie wszystkich, a tych, którzy uciekają od wojen i głodu, i których prawo do wolności religijnej czy życia jest naruszane [...] rzeczywistych uchodźców, a nie wszystkich uciekinierów (Fronda.pl).

Pierwszymi ofiarami radykalnego islamizmu są zaś chrześcijanie. I na ich przyjęcie możemy i powinniśmy być otwarci (Fronda.pl).

[...] papież rozróżnił sytuację przybywających na Stary Kontynent w celach zarobkowych oraz uchodźców ze stref objętych konfliktami zbrojnymi (Fronda.pl).

Oto bowiem okazuje się, że papież nie ma też nic przeciwko polskiej postawie wobec imigrantów (Fronda.pl).

Czy papież powiedział, że potrzebna jest gotowość przyjęcia tych, którzy uciekają od wojen i głodu (ważne: bez wskazania ich wyznania)? Tak (Deon.pl).

[...] papieska wypowiedź w odniesieniu do uchodźców miała charakter analityczny. Ojciec św. mówi o gotowości przyjęcia ludzi uciekających od wojen i głodu, co wyraźnie wskazuje na uchodźców. A to nie jest to samo, co emigranci zarobkowi - zauważył (Deon.pl).

Bardzo mocne było sformułowanie o otwartości serca na ludzi potrzebujących, na ludzi, którzy uciekają przed wojną, na uchodźców. To wybrzmiało mocno (Deon.pl).

[...] papież podkreśla konieczność solidarności z potrzebującymi oraz ochronę życia, co nie odnosi się tylko do uchodźców, ale wszystkich będących w trudnej sytuacji (Deon.pl).

[...] każde życie należy chronić, a także przyjmować tych, którzy potrzebują pomocy. Nie odczytuję tych słów tylko w kontekście imigrantów i uchodźców, ale przede wszystkim jako wezwanie do pomocy wszystkim potrzebującym (Deon.pl).

[...] nie ma żadnych istotnych różnic między Kościołem w Polsce, wiernymi w naszym kraju a papieżem Franciszkiem. Główne rozbieżności między Polską a papieskim nauczaniem dostrzegane są w podejściu do tematu uchodźców. Tymczasem polscy biskupi mówią w tej sprawie jednym głosem, podkreślając, że nie można zmienić Ewangelii i że jest oczywiste, że pomoc uchodźcom jest chrześcijańskim obowiązkiem (Deon.pl). 
[...] papież oprócz wątków duszpasterskich poruszył też problem emigracji (Wiara.pl). A jeśli zjawiają się „kolorowi”, to też problemu nie mamy (Wiara.pl).

Ksenofobiczne czasy PRL-u dawno minęły, teraz młodzi dogadują się między sobą dość dobrze, często bardzo dobrze (Wiara.pl).

Nie dajmy sobie zatem wmówić, że nie lubimy czy boimy się obcokrajowców. Nie dajmy sobie wmówić jakiejś rzekomej ksenofobii. Ani w nią wpędzić (Wiara.pl).

\section{Nauczanie papieża Franciszka o uchodźcach a jego przekaz na katolickich stronach internetowych}

Między nauczaniem papieża o uchodźcach a relacjami dziennikarzy zamieszczonymi na stronach katolickich portali zachodzą treściowe różnice. Pokazują to analizy ilościowe i jakościowe. $\mathrm{Z}$ analiz ilościowych wynika, że na siedemnaście tekstów o uchodźcach znajdujących się na analizowanych portalach, jedynie trzy były w miarę wiernym przekazem nauczania papieskiego. Oto one ${ }^{7}$ :

Nie zabrakło także odniesienia do problemu uchodźców. Papież prosił o mądrość i miłosierdzie w podejściu do problemów migracyjnych.

Ta ostatnia kwestia [uchodźców] wymaga dodatkowo mądrości i miłosierdzia, aby przezwyciężyć lęki i zrealizować największe dobro;

Czy papież powiedział, że potrzebna jest gotowość przyjęcia tych, którzy uciekają od wojen i głodu (ważne: bez wskazania ich wyznania)? Tak.

[...] potrzebna jest gotowość przyjęcia ludzi uciekających od wojen i głodu; solidarność z osobami pozbawionymi swoich praw podstawowych, w tym do swobodnego i bezpiecznego wyznawania swojej wiary;

Bardzo mocne było sformułowanie o otwartości serca na ludzi potrzebujących, na ludzi, którzy uciekają przed wojną, na uchodźców. To wybrzmiało mocno.

Serce miłosierne potrafi być schronieniem dla tych, którzy nigdy nie mieli domu albo go stracili, potrafi stworzyć atmosferę domu i rodziny dla tych, którzy musieli emigrować, jest zdolne do czułości i współczucia.

7 W tej części artykułu słowa dziennikarzy umieszcza się przed słowami papieża Franciszka. Dzieje się tak, ponieważ te pierwsze są przedmiotem badań, a drugie pełnią jedynie rolę kontrolną. 
Natomiast badania jakościowe pokazują, że dziennikarze na różne sposoby „rozmywali” nauczanie papieża Franciszka o uchodźcach. Jedni jego słowa komentowali w oderwaniu od kontekstu (1), kolejni apel o pomoc uchodźcom rozszerzali na innych potrzebujących (2), a jeszcze inni sugerowali, że papież miał na myśli tylko uchodźców, a nie imigrantów (3). Byli też i tacy dziennikarze, którzy usiłowali bagatelizować problemi mówili o „rzekomej” ksenofobii (4), albo tacy, którzy wprost przeczyli papieskiemu nauczaniu (5).

(1) [...] papież oprócz wątków duszpasterskich poruszył też problem emigracji. Trzeba zidentyfikować przyczyny emigracji z Polski, ułatwiając powrót osobom, które chcą wrócić. Jednocześnie potrzebna jest gotowość przyjęcia ludzi uciekających od wojen i głodu; solidarność z osobami pozbawionymi swoich praw podstawowych, w tym do swobodnego i bezpiecznego wyznawania swojej wiary. Równocześnie należy zabiegać o współpracę i koordynację na poziomie międzynarodowym, w celu znalezienia rozwiązania konfliktów i wojen, które zmuszają wielu ludzi do opuszczenia swoich domów i ojczyzny.

(2) [...] papież podkreśla konieczność solidarności z potrzebującymi oraz ochronę życia, co nie odnosi się tylko do uchodźców, ale wszystkich będących w trudnej sytuacji.

Pójść na ulice, naśladując „szaleństwo” naszego Boga, który uczy nas spotykania Go w głodnym, spragnionym, nagim, chorym, w przyjacielu, który źle skończył, w więźniu, w uchodźcy i w imigrancie, w człowieku bliskim, który jest samotny.

(3) [...] papieska wypowiedź w odniesieniu do uchodźców miała charakter analityczny. Ojciec św. mówi o gotowości przyjęcia ludzi uciekających od wojen i głodu, co wyraźnie wskazuje na uchodźców. A to nie jest to samo, co emigranci zarobkowi - zauważył.

Serce miłosierne potrafi dzielić swój chleb z głodnym, serce miłosierne otwiera się, aby przyjmować uchodźców oraz imigrantów.

(4) Nie dajmy sobie zatem wmówić, że nie lubimy czy boimy się obcokrajowców. Nie dajmy sobie wmówić jakiejś rzekomej ksenofobii. Ani w nią wpędzić.

Naucz nas jak Marię z Betanii słuchania tych, których nie rozumiemy, tych, którzy pochodzą z innych kultur, innych narodów, a także tych, których się boimy, sądząc, że mogą nam wyrządzić zło.

(5) Oto bowiem okazuje się, że papież nie ma też nic przeciwko polskiej postawie wobec imigrantów.

W odniesieniu do imigrantów, powiem że problem tkwi tam, w ich ojczyźnie. Ale jak ich przyjmiemy? Sądzę, że każdy kraj musi zobaczyć, w jaki sposób i kiedy. Nie wszystkie kraje są równe. Nie wszystkie kraje mają takie same możliwości. [...] Ilu i jak? Nie można dać odpowiedzi uniwersalnej ponieważ gościnność zależy od sytuacji każdego kraju, a także kultury. Ale oczywiście można zrobić wielkie rzeczy. Na przykład modlitwa: cotygodniowe adoracje Najświętszego Sakramentu. 
Jak wytłumaczyć różnice między nauczaniem papieża o uchodźcach a treściami zamieszczonymi na stronach katolickich portali? Wydaje się, że różnice te wynikają ze sposobów funkcjonowania mediów, których częścią są portale społecznościowe. Charakterystyczną cechą mediów jest dzisiaj troska o zgodność propagowanych treści z nastawieniem społecznym. Innymi słowy media, przekazując i filtrując informacje, starają się zaspokoić oczekiwania odbiorców ${ }^{8}$. Tak też było z nauczaniem papieża Franciszka o uchodźcach. Dziennikarze katolickich portali internetowych starali się nauczanie to dostosować do potrzeb swoich odbiorców. Dlatego w kwestiach spornych łagodzili wypowiedzi papieża, zastępując kłopotliwe słowa innymi, bardziej naturalnymi. Tam, gdzie jego słowa wydawały się radykalne, osłabiali je, dokonując ich dekontekstualizacji. A w sytuacjach skrajnych, gdy nauczanie to było niezgodne z poglądami odbiorców, posuwali się nawet do jego negowania.

Inną istotną cechą mediów jest ich kreatywność. Oznacza to, że media nie tylko odpowiadają na zainteresowanie odbiorców, ale to zainteresowanie wzbudzają, podsycają lub gaszą. Tak widziane są kreatorami - mówią, o czym mamy myśleć i w jaki sposób. Tym bardziej poprzez sposób podawania wiadomości, relacjonowania i komentowania ich sugerują, podsuwają, a wielokrotnie narzucają opinie odbiorcom. Oddziaływanie takie charakteryzuje nie tylko media tradycyjne (czyli prasę, radio czy telewizję), ale i media cyfrowe, których przestrzenią działania jest internet. Do takich z pewnością zaliczają się rozmaite portale informacyjne, które mają swoich specyficznych odbiorców, tzn. takich, którzy tylko z nich czerpią informacje o świecie. Niezależnie jednak od charakterystyki danego typu medium, jego siła oddziaływania nie ulega wątpliwości ${ }^{9}$.

Ostatnią ważną z punktu widzenia niniejszego opracowania cechą mediów jest swego rodzaju subiektywizm w relacjonowaniu wydarzeń. Zwraca na to uwagę Walter Lippman: „Żadna relacja określonego wydarzenia nie odzwierciedla rzeczywistości. Każde jego ujęcie przez obserwa-

8 Por. T. Goban-Klass, Media i komunikowanie masowe. Teorie i analizy prasy, radia, telewizji i Internetu, Warszawa-Kraków 2002, s. 129.

9 Szeroko na ten temat pisze: A. Kozłowska, Oddziaływanie mass mediów, Warszawa 2006. 
tora stanowi interpretację"10. Nie jest zatem obojętne, w jakim kontekście dane słowa są cytowane, $w$ jaki sposób przedstawiane i jak komentowane. Nawet najbardziej obiektywne streszczenia przemówień nie są wolne od subiektywnego wyboru cytatów, podkreślania jednych i pomijania innych słów.Jedynym niewartościującym sposobem relacjonowania jest zamieszczenie całego przemówienia dokładnie w takiej postaci, w jakiej zostało wygłoszone. Media rzadko jednak sięgają po ten model. Z różnych oczywiście względów, także czysto technicznych.

\section{Wpływ mediów na recepcję nauczania papieża Franciszka o uchodźcach}

Dane CBOS-u z pierwszej połowy 2016 roku pokazują, że niechętnych przyjmowaniu przez Polskę uchodźców było $60-75$ procent Polaków ${ }^{11}$. Natomiast z badań sondażowych przeprowadzonych przez „Rzeczpospolitą” poŚwiatowych Dniach Młodzieży wynika, że niechętnych wobec uchodźców było 67 procent badanych ${ }^{12}$. Oznacza to, że nauczanie papieża Franciszka nie zmieniło nastawienia Polaków do uchodźców. W takiej sytuacji musi zrodzić się pytanie: Dlaczego tak się stało? Złożyło się na to kilka czynników, ale z dużym prawdopodobieństwem można powiedzieć, że na taki wynik ogromny wpływ miały media publiczne i prawicowe, które nauczanie papieża opatrywały własnym komentarzem lub - podobnie jak portale katolickie - zastępowały je dziennikarską interpretacją. Za słusznością tej tezy przemawia fakt, że Polacy informacje o pielgrzymce i nauczaniu papieskim czerpali przede wszystkim z mediów. Świadczy o tym sondaż przygotowany przez CBOS w dniach 17-25 sierpnia 2016 roku dotyczą-

10 Cyt. za: M. Dorenda-Zaborowicz, Nowe media w służbie marketingu politycznego, w: Nowe media a praktyki komunikacyjne, red. K. Pokorna-Ignatowicz i in., Kraków 2013, s. 51.

11 Dane opublikowane na stronach CBOS, http://www.cbos.pl/PL/publikacje/raporty. php (15-30.11.2016).

${ }_{12}$ W rozbiciu na sympatie polityczne widać, że papież nie trafił do elektoratu Kukiz'15i PiS. Żaden wyborca ruchu Pawła Kukiza nie zadeklarował zmiany postawy w kwestii uchodźców. Wśród wyborców PiS deklarację o zmianie złożyło jedynie 18 proc. badanych. Większą wrażliwość na słowa papieża Franciszka w tej kwestii zadeklarowali wyborcy Nowoczesnej (58 proc.) i PO (48 proc.). Por. T. Krzyżak, Papież grochem o ścianę, „Rzeczpospolita” 17.08.2016, nr 5. 
cy zainteresowania wizytą papieską w Polsce. Aż 63 proc. ankietowanych zadeklarowało, że śledziło przebieg wizyty Franciszka, z czego większość za pośrednictwem mediów z komentarzami dziennikarzy ${ }^{13}$. Pełną i miarodajną odpowiedź na powyższe pytanie mogłyby przynieść stosowne badania, których - jak dotąd - w Polsce nie przeprowadzono.

$$
*^{*} *
$$

Obecny na Światowych Dniach Młodzieży w Krakowie papież wygłosił sześć przemówień, w których zaapelował o przyjmowanie uchodźców z Bliskiego Wschodu i innych regionów świata. Polacy ten apel zapamiętali, ale nie zmienili niechętnego nastawienia do uchodźców. Było to w dużym stopniu „zasługą” między innymi katolickich portali internetowych, które - zamiast słów papieskich - przekazywały odbiorcom luźną ich interpretację.

13 Por. sondaż dla Polskiego Radia: http://www.polskieradio.pl/5/3/Artykul/1664619,Ilu-Polakow-sledzilo-przebieg-wizyty-papieza-podczas-SDM-Sondaz-CBOS (10.10.2016). 


\section{Summary}

Nauczanie papieża Franciszka o uchodźcach podczas Światowych Dni Młodzieży w Krakowie w relacjach dziennikarzy katolickich portali internetowych

Na treść opracowania złożyły się rozważania o recepcji nauczania papieża Franciszka na temat uchodźców podczas Światowych Dni Młodzieży w Krakowie. Celem zaś była odpowiedź na pytanie, jak papieskie nauczanie o uchodźcach było przedstawiane na stronach katolickich portali internetowych. Z przeprowadzonych badań wynika, że na stronach tych były zamieszczane dziennikarskie interpretacje papieskich słów o uchodźcach, a nie jego słowa. To mogła być jedna z przyczyn, że Polacy pozostali „nieugięci” i nie zmienili swojego negatywnego nastawienia do uchodźców.

Słowa kluczowe: Światowe Dni Młodzieży, papież Franciszek, uchodźcy, recepcja, katolickie portale internetowe

Presentation of Pope Francis' teaching on refugees during the World Youth Day in Krakow in reports of Polish catholic web portals

The study focused on the reception of Pope Francis' teaching on refugees during the World Youth Day in Krakow. Its aim was to answer the question of how the Pope's teaching on refugees was presented on Polish Catholic web portals. The research shows that the portals presented journalists' interpretations of Pope's words concerning refugees, not his own words. This could have been one of the reasons why the Poles have remained adamant in their negative attitudes towards refugees.

Keywords: World Youth Day, Pope Francis, refugees, reception, catholic web portals

\section{Bibliografia}

deon.pl (25.07 - 02.08.2016).

Dorenda-Zaborowicz M., Nowe media w służbie marketingu politycznego, w: Nowe media a praktyki komunikacyjne, red. K. Pokorna-Ignatowicz i in., Kraków 2013, s. 36-62.

fronda.pl (25.07-02.08.2016).

Goban-Klass T., Media i komunikowanie masowe. Teorie i analizy prasy, radia, telewizji i Internetu, Warszawa-Kraków 2002.

Guzek D., Konwergencja mediów katolickich w Polsce, w: Konwergencja mediów masowych i jej skutki dla współczesnego dziennikarstwa, t. 2, red. M. Gierula, P. Szostok, Katowice 2012, s. 227-240.

Kozłowska A., Oddziaływanie mass mediów, Warszawa 2006. 
Krzyżak T., Papież grochem o ścianę, „Rzeczpospolita” 17.08.2016, s. 5.

Laboratorium Więzi: Franciszek w Polsce. Co powiedział papież podczas Światowych Dni Młodzieży, www.laboratorium.wiez.pl (14.09.2016).

wiara.pl (25.07 - 02.08.2016).

Wójcik P., Strachy na Lachy, „Tygodnik Powszechny” 25 (2017), s. 26-27. 